\title{
MENGENAL IDENTITAS MASYARAKAT BUTON MELALUI KONSEP BERKELUARGA DALAM KABANTI KALUKU PANDA
}

\author{
Kosilah $^{1}$ S. Hafidhawati Andarias ${ }^{2}$ \\ Program Studi Pendidikan Guru Sekolah Dasar, Fakultas Keguruan dan Ilmu Pendidikan, \\ Program Studi Pendidikan Biologi, Fakultas Keguruan dan Ilmu Pendidikan, \\ Universitas Muhammadiyah Buton, Jl. Betoambari No. 36 Baubau. \\ E-mail:kosilah81@gmail.com fidha.andarias@gmail.com
}

\begin{abstract}
Abstrak
Tujuan penelitian ini adalah untuk mengetahui identitas masyarakat Buton melalui konsep berkeluarga yang terdapat dalam Kabanti Kaluku Panda. Hasil penelitian dalam kabanti Kaluku Panda tersebut di dalamnya mengandung konsep-konsep ketuhanan, konsep seks dan konsep berkehidupan sosial baik dalam bermasyarakat maupun tata cara dalam membina sebuah keluarga. Konsep berumah tangga pada masyarakat Buton adalah konsep yang mengikuti ajaran agama islam dalam membangun rumah tangga, yakni konsep sakinah, mawaddah wa rahmah dan senantiasa menjaga kesetiaan dalam hubungan. Larangan yang paling fatal dalam pernikahan yakni adanya pelanggaran batas atau zina maka hukumannya sangatlah berat. Adapun prosesi menuju kehidupan dalam berumah tangga di masyarakat Buton sangatlah detil dan panjang urutannya. Dimulai dari persiapan, pemilihan, prosesi pernikahan hingga konsep seks dalam berhubungan setelah berumah tangga menjadi konsep nilai yang sangat berharga demi terciptanya sebuah generasi yang baik.
\end{abstract}

Kata kunci: konsep berkeluarga, masyarakat Buton.

\begin{abstract}
The purpose of this study was to determine the identity of the Butonese community through a family concept found in Kabanti Kaluku Panda. The results of the research in the Kaluku Panda kabanti contained the concepts of divinity, the concept of sex and the concept of social life both in society and in the procedures for fostering a family. The concept of marriage in Buton society is a concept that follows the teachings of Islam in building a household, namely the concept of sakinah, mawaddah wa rohmah and always maintaining loyalty in relationships. The most fatal prohibition in marriage is the existence of a violation of boundaries or adultery, the punishment is very severe. The procession towards living in a household in the community of Buton is very detailed and in length. Starting from preparation, election, marriage procession to the concept of sex in intercourse after marriage becomes a very valuable concept of value for the creation of a good generation.
\end{abstract}

Keywords: family concept, Buton community. 


\section{SANG PENCERAH}

Volume 3, Nomor 2, Agustus 2017, Hlm. 39-49

Kosilah: Mengenal Identitas Masyarakat Buton melalui Konsep ...

\section{Pendahuluan}

Berkehidupan sosial dan bernegara merupakan media manusia untuk senantiasa berinteraksi antara satu dengan yang lainnya agar terus dapat eksis dan bertumbuh dan berkembang meneruskan kehidupan seiring dengan berjalannya zaman. Salah satu cara untuk dapat berinterakasi baik dengan masyarakat sekitarnya, manusia acapkali perlu menanamkan nilai-nilai yang tidak bertentangan dengan norma dan hukum di sekelilingnya. Hal ini menjadi sangat wajar mengingat karakter manusia dalam setiap daerah berbeda-beda. Pun demikian dengan kondisi geografis dan demografis yang bervariatif pulalah yang menyebabkan faktor-faktor keberagaman itu muncul pada setiap individu.

Indonesia adalah negara yang dapat mengontrol keselarasan hidup bermasyarakat yang beragam. Alat kontrol inilah yang sekaligus dijadikan sebagai identitas bangsa ini. Pancasila dengan kelima silanya menjadi senjata yang ampuh untuk membingkai keaneka ragaman tersebut dalam bangsa yang besar ini. Patutlah dibanggakan hingga ahirnnya bangsa ini mempunyai satu pandangan dalam melihat keberagaman yang begitu majemuk. Identitas bangsa ini menjadi ujung tombak untuk mengatasi berbagai hal yang membuat keresahan bangsa ini.

Dewasa ini, tak sedikit para generasi muda memilih jalan yang salah dalam mengekspresikan bentuk 'kebebasan'nya. Perbuatan asusila yang bertentangan dengan pancasila pun bukan lagi menjadi hal yang tabu dan perlu ditutup-tutupi lagi. Tawuran antar pelajar, seks bebas yang menjadi trend, penggunaan miras dan barang-barang haram lainnya menjadi pilihan utama untuk solusi cepat dalam menghadapi segala masalah hingga norma adat istiadatpun tak lagi menjadi warisan yang dipandang perlu untuk diturunkan terhadap anak cucu sebagai generasi penerus keberlangsungan kehidupan dalam masyarakat. Untuk itulah nilai-nilai budaya yang mempunyai nilai luhur sudah tak banyak lagi diketahui oleh para penerus bangsa ini.

Nilai kearifan lokal dalam setiap daerah di Indonesia menjadi ujung tombak pembentukan karakter generasi bangsa ini. Sastra mengambil peran juga dalam hal ini. Sejak zaman dahulu kala, peran karya-karya sastra di setiap daerah menjadi pilihan untuk menyampaikan pesan-pesan positif dalam masyarakat.sehingga karakter yang berbudi bisa terbentuk dan tercipta dalam keluarga dan masyarakat luas. Sastra dengan medium bahasanya yang indah mampu masuk dalam nurani masyarakat Indonesia, memperhalus budi dan menajamkan akal. Seperti fungsinya, sastra tak hanya menghibur dengan membawa kesenangan karen halus dan indah bahasanya naun, lebih dari itu membawa pendidkan dan pengetahuan yang terbungkus dalam pesan dan maanat yang dibawanya.

Kabanti adalah syair yang ditulis dengan bahasa Wolio yang merupakan karya sastra lama yang terdapat di daratan pulau Buton. Nilai-nilai moral dan nilai agama yan gkental dalam Kabanti ini menjadi bekal pedoman hidup masyarakat Buton dari zaman dahulu hingga sekarang. Meskipun saat ini sedikit berbeda dengan zaman dahulu yang menganggap segala perilaku adat itu pantang untuk tidak dilaksanakan secara penuh. Generasi sekarang lebih suka pada hal-hal yang bersifat praktis dan efektif hingga tradisi leluhurpun sah-sah saja di 'pangkas' selama itu dianggap lebih praktis dan efektif tanpa mempertimbangkan esensi nilai sejatinya dari tradisi tersebut. Sebagai contoh nyata, setiap salah satu dari anggota masyarakat di Buton sudah jarang sekali kita dapati jika suatu masa mempunyai hajat besar seperti menikahkkan anak mereka, tak lagi mengundang tetangga dan sanak saudara untuk bersama-sama memasaka menyajikan sajian untuk keperluan hajat tersebut. Jasa 


\section{SANG PENCERAH}

Volume 3, Nomor 2, Agustus 2017, Hlm. 39-49

Kosilah: Mengenal Identitas Masyarakat Buton melalui Konsep ...

katering makanan menjadi pilihan utama untuk menyelesaikan persoalan itu. Lebih praktis dan efektif kilahnya. Padahal esensi dari nilai kebersamaan itu adalah adanya kegotong-royongan antar sesama sehingga ikatan persaudaraan antar sesama erat terjalin dan berlangsung lama. Semuanya kini perlahan tapi pasti, tergerus oleh zaman dan era instan yang haus nilai-nilai tradisi.

Masyarakat Buton adalah salah satu masyarakat yang masih menjaga adat dan bisa kita lihat kekentalan tradisinya dalam beberapa sisi kehidupannya. Salah satunya adalah yang terdapat dalam tradisi pernikahan dan berkeluarga. Hingga saat ini perhitungan adat masih dan terkesan harus dipikirkan dalam proses sebelum pernikahan. Pemberian wejangan pun dari tetua adat atau salah satu yang dituakan dalam keluarga pun masih dilakukan meski urutan prosesi sudah tak seharusnya dilewati. Pingitan misalnya, tak banyak lagi yang menjalankannya selama tujuh hari tujuh malam, bisa dilewati hanya semalam saja dengan maksud seolah sebagai 'penggugur' prosesi adat saja. Kilahnya cukup sederhana, yang penting kita tahu apa maksud dan tujuannya, wejangan pun bisa dilakukan kapan saja. Sah-sah saja memang tapi alangkah lebih baiknya jika kita dapat mengetahui dan masih menjalankan apa yang sudah menjadi tradisi tetua yang tak ada salahnya tetap kita penuhi demi bekal keberlangsungan hidup nanti.

Kabanti Kaluku Panda ini sarat dengan nasehat dan pengingat bagi siapa saja yang hidup bermasyarakat di bumi ini. Dengan sekilas membacanya saja paling tidak seseorang akan membenarkan nilai luhur yang sejatinya tak ada salahnya untuk terus dilestarikan. Segala proses dan himbauan yang sarat dengan nilai moral dan agama dalam karya sastra lama ini digambarkan dengan tidak lugas. Selayaknya syair dan petuah masa lampau isi dari Kabanti Kaluku Panda ini memerlukan penjelasan dan uraian akan makna sesungguhnya. Namun satu hal yang dapat diperhatikan bahwa pada akhirnya pesan moral dan pesan agama yang dibawa oleh syair-syair tersebut menjadi konsep berkeluarga (bermasyarakat) yang menginginkan terciptannya generasi yang baik dan bermartabat, selaras dengan identitas bangsa ini. Berdasarkan deskripsi di atas, fokus penelitian ini bagaimanakah identitas masyarakat Buton melalui konsep berkeluarga yang terdapat dalam Kabanti Kaluku Panda?

Tujuan penelitian ini adalah untuk mengetahui identitas masyarakat Buton melalui konsep berkeluarga yang terdapat dalam Kabanti Kaluku Panda.

\section{Metode Penelitian}

Metode yang digunakan dalam penelitian ini adalah metode deskriptif kualitatif yang bertujuan untuk mendeskripsikan identitas masyarakat Buton melalui konsep berkeluarga yang terdapat dalam Kabanti Kaluku Panda. Jenis penelitian yang digunakan adalah penelitian kepustakaan (library research). Sumber data dalam penelitian ini adalah data tertulis yang diperoleh melalui teks Kabanti Kaluku Panda.

\section{Pembahasan}

\section{Masyarakat Buton dan Identitasnya}

Berbicara mengenai identitas sebenarnya adalah label atau ciri khas tertentu yang tertambat pada diri seseorang. Sehingga jika identitas yang dimaksud adalah identitas yang melekat pada daerah atau wilayah tertentu, maka bisa diasumsikan bahwa hal ini sejalan dengan definisi identitas yang kemukakan oleh Wahyono (2009) berikut ini. Identitas suatu bangsa adalah cerminan dari pola 


\section{SANG PENCERAH}

Volume 3, Nomor 2, Agustus 2017, Hlm. 39-49

\section{Kosilah: Mengenal Identitas Masyarakat Buton melalui Konsep ...}

kehidupan masyarakat dalam berbangsa dan bernegara, serta penyelenggaraaan kehidupan demokrasi (kedaulatan rakyat) dan berperi kemanusiaan yang ada di negara tersebut. Sebuah bangsa adalah kumpulan dari masyarakat yang hidup dalam satu kesatuan. Lebih jelasnya lagi seperti yang dijelaskan oleh Prayitno dalam Wahyono (2009) menambahkan bahwa bangsa berarti komunitas manusia yang memiliki nama/identitas bersama, memiliki keyakinan, komitmen dan sejarah yang besama, memiliki budaya publik bersama, memiliki hak dan kewajiban yang sama bagi anggotanya dan menguasai tanah air bersama.

Adapun menurut sumber yang sama bahwa pembinaan identitas bangsa secara dinamis dan terus menerus sebagai upaya menanamkan karkater dann pondasi kebangsaan (character and nation building) adalah elemen pokok yan gmemperkuat pembentukan persaudaraan bangsa dan memperkuat ketahanan bangsa tersebut. Hal ini menjadi jelas adalah jika kita membahas mengenai salah satu komunitas atau daerah yang menjadi bagian dari satu kesatuan berarti kita menjadi bagian yang tak terpisahkan dari kesatuan itu. Seperti halnya masyarakat Buton yang menjadi bagian dari wilayah kesatuan Indonesia. Oleh karenanya segala bentuk budaya dan kebiasaaan berkehidupannya tentulah pada akhirnya akan mencerminkan identitas bangsa tersebut.

Kesediaan warga negara/bangsa untuk mendukung identitas nasional perlu di tanamkan dan dipupuk serta dikembangkan terus menerus. Hal ini dilakukan karena warga terlebih dahulu memiliki identitas kelompoknya, sehingga jangan sampai melunturkan identitas bangsa/nasional. Adapun bentuk identitas kebangsaan bisa berupa adat istiadat, bahasa nasional, lambang nasional, bendera nasional termasuk juga ideologi nasional. Dengan tidak memungkiri adanya faktor- faktor yang mempengaruhinya. Faktor geografis dan demografis, faktor kesejarahan dan faktor kebudayaan yang notabene masih sama yakni nusantara menjadikan identitas masyarakat Buton memiliki sumbang sih bagi keanekaragaman kekayaan budaya bangsa ini. Hal ini senada dengan pernyataan berikut bahwa identitas nasional suatu negara pada hakikatnya merupakan suatu bentuk kepribadian bangsa yang sesungguhnya untuk mewujudkan kredibilitas, integritas, harkat dan martabat bangsa dalam rangka mencapai tujuan negara.

Buton adalah nama sebuah pulau sepanjang kurang lebih $100 \mathrm{~km}$ yang terletak di dalam sisi tenggara jazirah Sulawesi (Maula, dkk. 2011). Daerah Buton adalah daerah yang awalnya memiliki nama butuun dengan bentuk pemerintahan kesultanan ini memiliki peradaban yang luar biasa kaya. Selain nama Butuun, nama Wolio juga direkatkan pada bentuk kerajaan tersebut pada masa lampau (Darmawan, 2009). Nama Wolio inilah kemudian disematkan juga dalam penamaan bahasa yang digunakan sebagai bahasa daerahnya. Bahasa ibu yang menjadi 'bahasa pemersatu' adalah bahasa Wolio yang penggunaannya telah dipahami dan dimengerti oleh orang Buton dan semua etnik yang tiggal di dalamnya (Palalloi, 2011). Bahasa wolio ini juga yang terdapat dalam hampir keseluruhan karya lokal berupa Kabanti. Hal ini penulis sampaikan mengingat penulis sampai saat ini belum mendapatkan karya-karya Kabanti yang memakai bahasa lain selain bahasa Wolio.

Masyarakat Buton terkenal ramah dan pekerja keras serta masih menjunjung beberapa kebiasaan spiritual yang mengesankan. Pelaksanaan adat istiadat yang sarat dengan nuansa Islam menjadi pemandangan sehari-hari di wilayah ini. Adanya pengantar adzan pada setiap akan dikumandangkannya adzan pada tiap waktu-waktu salat membuat senantiasa mengingatkan pada setiap orang bahwa 


\section{SANG PENCERAH}

Volume 3, Nomor 2, Agustus 2017, Hlm. 39-49

\section{Kosilah: Mengenal Identitas Masyarakat Buton melalui Konsep ...}

masyarakat Buton ini adalah mayoritas penganut agama islam. Selain itu rincian prosesi adat yang sarat dengan doa-doa berbahasa Arab dan Wolio juga memperindah nuansa kombinasi yang sakral dalam tiap prosesi adat baik dalam tahap manusia lahir, hidup maupaun saat meninggal. Etika tradisional yang masih erat dijalankan dalam masyarakat Buton ini adalah ramah, suka menolong, menyayangi orang lain dan tidak suka menyendiri menjadi kebiasaan dalam tatanan hidup bernegara dan berbangsa (Zaadi, 2005). Dengan demikian masyarakat Buton menjadi pribadi yang menarik dan berwibawa dalam menjalani pergaulan dalam bermasyarakat luas.

Sebuah masyarakat adalah kumpulan dari beberapa keluarga. Sebuah keluarga dibangun dari dua insan yang mempunyai rasa cinta kasih yang tulus. Rasa cinta dan kasih sayang pasti dan akan dialami oleh setiap manusia. Di dalam kehidupan berumah tangga, kasih sayang merupakan kunci kebahagiaan (Widagdho, dkk. 2008). Hampir di semua agama dan aliran kepercayaan, rasa kasih sayang diterapkan baik secara vertikal maupun horisontal. Adanya sebuah komunitas atau bangsa juga diawali oleh penyatuan rasa cinta dan kasih sayang terhadap sesama manusia. Berkeluarga adalah pilihan sarana untuk penyatuan tersebut. Menurut Friedman (2012), Fungsi keluarga adalah sebagai berikut: 1) Fungsi afektif, mengajarkan segala sesuatu untuk mempersiapkan anggota keluarganya dalam berhubungan dengan orang lain, 2) Fungsi soialisasi, mengembangkan dan sebagai tempat melatih anak untuk berkehidupan sosial sebelum meninggalkan rumah untk berhubungan dengan orang lain, 3) Fungsi reproduksi, fungsi untuk memepertahankan generasi dan menjaga kelangsungan keluarga, 4) Fungsi ekonomi, fungsi keluarga untuk memenuhi kebutuhan keluarga secara ekonomi dan tempat untuk mengembangkan kemampuan individu dalam meningkatkan penghasilan dalam rangka memenuhi kebutuhan dan 5) Fungsi pemeliharaan kesehatan, fungsi untuk mempertahankan keadaan kesehatan anggota keluarga agar tetap memiliki produktivitas yang tinggi. Mengingat begitu sangatlah penting dan positif fungsi keluarga maka sangatlah wajar jika berkeluarga merupakan pilihan yang tepat bagi generasi bangsa yang sudah memiliki pasangan yang cocok dan kesipaan baik secara mental, spiritual maupun finansial.

Berkeluarga adalah proses dimana seseorang telah melalui proses pernikahan. Menurut Sudarsono (1992) pernikahan adalah suatu ikatan suci dan luhur antara seorang perempuan dan seorang laki-laki menjadi suami istri dan dihalalkan hubungan seksual dengan tujuan mencapai keluarga sakinah, penuh kasih sayang, kebajikan dan saling menyantun. Dengan adanya pernyataan tersebut maka jelaslah bahwa sesungguhnya konsep umum dalam pernikahan dan berkeluarga adalah dasardasar berkeluarga yang mempunyai tujuan bahagia bersama. Dalam islam, sebuah pernikahan yang berhasil ada beberapa syarat dan hal ini menjadi konsep dasar dalam berkeluarga, yakni (1) Dapat memilih pasangan yang baik, hal ini sesuai dengan as-sunah dari ibnu majah dan at-Tirmidzi yang mengatakan bahwa 'Jika datang pada kalian orang yang baik akhlak dan agamanya. Nikahkanlah dia (dengan keluargamu)'; (2) Menjalani pernikahan dengan sukarela artinya tidak ada unsur paksaan; (3) Terjadinya kewajiban menggauli dan saling bergaul (memperlakukan pasangan) dengan baik; dan (4) Masing-masing suami dan istri mendapat memenuhi hak dan kewajiban secara seimbang dan bersama-sama. Hal ini sebagaimana yang tertuang dalam Q.S Arrum (30):21 yang artinya 'dan diantara tandatanda kekuasaan-Nya iyalah Dia yang menciptakan untukmu isteri-isteri dari jenismu 


\section{SANG PENCERAH}

Volume 3, Nomor 2, Agustus 2017, Hlm. 39-49

\section{Kosilah: Mengenal Identitas Masyarakat Buton melalui Konsep ...}

sendiri, supaya kamu cenderung dan erasa tentram kepadanya, dan dijadikannya diantara kamu rasa kasih dan sayang. Sesungguhnya pada yang demikian itu benar-benar terdapat tandatanda bagi kaum yang berfikir'.

Selain itu dalam Undang-undang Nomor: 1 Tahun 1974 tentang perkawinan, pasal 1 menyatakan bahwa perkawinan adalah ikatan lahir dan batin antara seorang pria dan wanita sebagai suami isteri dengna tujuan membentuk keluarga yang bahagia dan kekal berdasarkan Ketuhanan Yang Maha Esa. Adapun Keluarga sakinah adalah keluarga yang dibina berdasarkan perkawinan yang sah, mampu memenuhi hajat hidup, spiritual dan materiil yang layak, mampu menciptakan suasana cinta kasih sayang selaras, serasi, seimbang dan mampu menanamkan nilai-nilai keimanan, ketakwaan, amal saleh dan akhlaqul karimah dalam lingkungan keluarga sesuai ajaran Islam. Lebih lanjut lagi bahwa intinya adalah keluarga sakinah menjadi tujuan dari semua konsep berkeluarga. Keluarga yang tangguh dan di dalamnya setiap anggota menemukan ketentraman jiwa (sakinah), batin dan diliputi cinta kasih (mawaddah) dan rahmat seperti apa yang disampaikan oleh Subhan (2004). Mengingat Buton dan masyarakatnya mayoritas beragama islam dan sempat juga sistem pemerintahannya juga berpedoman pada islam, maka konsep berkeluarga dalam Kabanti Kaluku Panda ini sedikit banyak merujuk pada konsep berkeluarga secara Islam.

\section{Kabanti Kaluku Panda}

Adapun ciri-ciri dari Kabanti sebagaimana pernyataan Rosdin dalam Darmawan (ed) adalah karya sastra ini terdiri atas sejumlah kalimat pendek, tidak mengandung rima, dan dalam penyajiannya biasanya dilagukan oleh tokoh tertentu (biasanya dari golongan tokoh agama.) kepada sekelompok individu atau khalayak ramai dengan harapan agar setiap pendengarnya dapat memetik hikmah dan pesan yang terkandung dalam karya tersebut (Rosdin dalam Darmawan: 296). Dengan demikian, dapat dinyatakan bahwa Kaluku Panda ini merupakan salah satu karya sastra lama yang merupakan karya yang mempunyai nilai luhur di dalamnya. Dikarenakan Kaluku Panda ini isinya merupakan kalimat-kalimat pendek berbahasa Wolio yang tersusun atas bait-bait dan tidak terikat oleh rima maka dapatlah Kaluku Panda ini merupakan salah satu Kabanti yang dimiliki oleh masyarakat Buton.

Kaluku Panda adalah salah satu karya sastra lama daerah Buton yang mempunyai 12 halaman dan terdiri dari 70 bait. Adapun pada setiap bait terdiri dari empat baris. Bahasa yang digunakan dalam Kabanti ini adalah bahasa Wolio dan beraksara Wolio pula. Aksara wolio ini adalah pada dasarnya berupa tulisan Arab namun, telah dilakukan beberapa pengembangan dan pencirian terhadap aksara tersebut yang merupakan ciri khusus aksara Wolio sesuai dengan bahasa yang digunakan pula sehingga dalam pembacaan dan penggunaan nya bisa dibedakan antara bunyi vokal dan konsonannya. Pengarang dari Kabanti Kaluku Panda ini adalah La Ode Kobu (Yarona Labuandiri) dan di terjemahkan dalam bahasa Indonesia oleh Arif Rahman dan di salin oleh Lambalangi pada tahun 2003. Kaluku Panda ini memiliki beberapa salinan dan versi, namun untuk kejelasan dan kepastian jumlah dah banyaknya versinya diperlukan penelitian lebih lanjut lagi. Kabanti Kaluku Panda yang dijadikan objek studi dan sumber data dalam penelitian ini adalah Kabanti Kaluku Panda yang mempunyai deskripsi seperti yang telah dijelaskan pada pernyataan sebelumnya. 


\section{SANG PENCERAH}

Volume 3, Nomor 2, Agustus 2017, Hlm. 39-49

Kosilah: Mengenal Identitas Masyarakat Buton melalui Konsep ...

\section{Identitas Masyarakat Buton dalam Kabanti Kaluku Panda}

Keluarga adalah komunitas terkecil dalam masyarakat, cikal bakal sebuah bangsa yang besar. Keberlangsungan tata cara dan kebiasaan dalam keluarga menjadi ciri dan penentu identitas bangsa itu sendiri. Setiap keluarga memiliki tata cara dan kebiasaaan sendiri-sendiri yang tak bisa disamakan, kebiasaan setiap keluarga dalam melangsukan kehidupan sehari-harilah yang akan menentukan dan memberikan ciri atau identitas siapa dan bagaimana keluarga itu dinilai dan ditempatkan dalam lingkungan masyarakat atau bahkan bangsanya. Begitupula dengan masyarakat Buton. Wilayah yang secara geografis terletak di bagian tengggara dari pulau sulawesi ini tentu memiliki keunikan tersendiri. Dalam hal ini dalam menerapkan kebiasaan dalam berkeluarga.

Masyarakat Buton yang mayoritas penduduknya beragama Islam dan sempat bentuk otoritas kepemimpinan daerahnya berbentuk kesultanan ini, tak mengherankan jika hampir seluruh konsep kehidupannya dilandaskan pada konsep keislaman. Konsep dalam menjalankan pemerintahan berlandaskan dengan konsep islam yang bahkan dalam tatanan keislaman berada pada tahap tasawuf. Hal tersebut secara detail di tuangkan dalam martabat tujuh. Begitupun dengan konsep berkeluarga yang nota bene mempunyai beberapa tujuan hidup, juga dilandaskan dalam konsep berkeluarga yang islami atau dilandaskan terhadap keimanan terhadap Tuhan yang Esa. Hal ini sesuai dengan apa yang tertuang dalam Pancasila Sila I yang berbunyi Ketuhanan Yang Maha Esa. Hal ini nampak dalam kabanti Kaluku Panda yang pada bait pertama, keenam, sebelas, dua belas, dua puluh, dua puluh tujuh dan dua puluh delapan. Pada bait bait tersebut dijelaskan mengenai nasehat dan arahan dalam hubungan secara vertikal antara manusia dengan tuhannya dalam segala hal yang berkenaan dalam kebidupan di dunia. Hal tersebut terlihat dalam contoh Kabanti Kaluku Panda pada bait pertama berikut:

Kupebaangi kusarongi Akbaru

Kuangkataka sarona Opu maoge

Sarona Opu moewauna dunia

Apepatai incana ilimuna

Yang mempunyai arti sebagai berikut:

Kubermula menyebut keagungan

Kuangkat tinggi nama Tuhan Maha Besar

Nama Tuhan yang telah mencipta dunia

Meliputi segala ilmunya.

Bait yang pertama tersebut merupakan penanda awal bahwa dalam Kabanti tersebut berdasar pada sifat keyakinan terhadap Tuhan yang Maha Esa. Ditambah lagi dengan bait berikut:

Poopusiya malo-malo konowiya

Senantiasea sara batua karomu

Siy saangu nizamu yoni Wolio

Yikarangina Batua momatambena

Yang memiliki arti sebagai berikut:

Jadikan Tuan hamba pagi dan sore

Senantiasa kau perhambakan dirimu

Inilah sebuah tembang bahasa Wolio

Yang dikarang seorang hamba nan hina

Penempatan rasa 'rendah hati' dan keyakinan akan kekuatan dan kebergantungan terhadap Tuhan Yang Maha Esa menjadi penanda tegas bahwa Kabanti yang di tulis ini dimulai dan sarat dengan nilai-nilai luhur berbasis islam karena dalam bait kedua dan ketiga disebutlah ada nabi, Rasulullah dan Jibril, serta penyebutan secara jelas mengenai kata Islam dan takwa dalam bait ke duapuluh dan dua puluh dua yang artinya bahwa istilah tersebut tentu merujuk pada agama Islam. Adapun permulaan dalam Kabanti ini yang menandakan bahwa penjelasan mengenai kehidupan berumah tangga dapat dilihat dari bait berikut:

Awaajibu yapai maanusia Malinguaka 'Aaqili baalega 


\section{SANG PENCERAH}

Volume 3, Nomor 2, Agustus 2017, Hlm. 39-49

\section{Kosilah: Mengenal Identitas Masyarakat Buton melalui Konsep ...}

Boli osea parinta inia itu

Osiytumo kawujuna syetani

Jika dialih bahasakan ke dalam bahasa

Indonesia adalah sebagai berikut

Adalah wajib bagi setiap manusia

Bagi yang mencapai umur aqil-baligh

Janganlah turuti perintah jelek itu

Itulah bujuk rayu setan iblis

Syair di atas menjelaskan batasan tentang tindakan yang seharusnya tidak dilakukan oleh seseorang yang cukup usia atau orang dewasa. Dan jika dihubungkan dengan syair sebelumnya dalam bait ke-31 hingga bait ke-36 menjadi landasan bahwa jika sudah masuk waktu menikah maka sebaiknya dilakukan pernikahan daripada terjadi perzinahan yang dapat merugikan diri sendiri dan orang lain. Hal ini sebagai penegasan tentang nilai yang terkandung dalam Kabanti ini berbicara mengenai ranah menuju masa berkeluarga dan konsep berkeluarga.

Dalam konsep keluarga islam pada dasarnya membangun keluarga adalah berlandaskan dengan rasa kasih sayang, cinta dan keberkahan. Dalam bahasa arab dikenal dengan sebutan sakinah, mawaddah wa rohmah. Hal tersebut menjadi konsep dan tujuan berkeluarga dalam Islam. Pun demikian pulalah yang tercermin dalam Kabanti Kaluku Panda ini dalam bait berbunyi:

Miyarangamu maasikeyampuu

Simbouduka umaasiaka karomu

Ositumo wine inda momabongko

Tokaindeana naile muri-murina

Mempunyai arti sebagai berikut:

Tuk sesamamu manusia sayangilah mereka

Seperti halnya menyayangi diri sendiri Demikian itulah bibit tak pernah rusak Untuk persemaian esok kemudian hari
Dalam bait di atas dapat dijelaskan bahwa dalam hubungan antar manusia atau sesama tentulah dasarnya adalah rasa kasih sayang yang dalam islam disebut dengan 'mawaddah'. Bait tersebut menjelaskan pula bahwa rasa kasih sayang itu merupakan hal pokok dan penting bagi keberlangsungan generasi berikutnya. Hal ini terungkap dari kata Tokaindeana atau persemaian yang berarti bahwa 'hasil' yang bisa diartikan adalah anak turun dan hasil dari kebersamaan. Jika dipupuk dengan rasa kasih sayang maka hasil persemaiannya akan baik.

Bahkan untuk menjaga 'kebaikan' hasil kebersamaan tersebut di tambahkan lagi dalam masa-masa berhubungan intimnya. Seperti yang terlihat pada bait empat puluh tiga hingga empat puluh delapan yang menerangkan masa-masa yang dianggap baik dalam berhubungan sehingga kelak akan menghasilkan generasi penerus yang baik dan mulia. Seperti bait berikut:

Eyo malape Jumaa teisinini

Teemoduka Araba'a tehamisi

Eyo madaki tewakutuu yipepali

Alaamatina akandeamparo-mparo

Artinya:

Hari baik adalah Jumat dan juga Senin Demikian juga hari rabu dan Kamis Hari buruk dan waktu yang dihindari Pertanda kan dimakan hama tanaman

Jika telah ada pertanda adanya persemaian artinya bahwa hubungan tersebut sudah ada hasil, yakni si perempuan mengandung maka haruslah ditambah dengan zikir dan takbir sebagai rasa syukur dan penjagaan terhadap hasil keturunan tersebut seperti yang tertuang dalam bait ke-50 yang berbunyi:

Kabubusina zikiri tetakbiru

Perawaina khaluwati teetoba

Adadiaka penembulamu siytu

Ositumo penembula yipiyara

Artinya:

Sirami pula dengan pupuk zikir dan takbir 


\section{SANG PENCERAH}

Volume 3, Nomor 2, Agustus 2017, Hlm. 39-49

\section{Kosilah: Mengenal Identitas Masyarakat Buton melalui Konsep ...}

Siangi ia dengan berkhalwat dan tobat

Bila telah tumbuh persemaianmu itu

Itulah tumbuhan yang perlu dipelihara

Selain itu ada beberapa larangan keras yang bisa merusak kehidupan berkeluarga yakni 'memasuki kebun' orang lain. Hal ini menyatakan bahwa kehidupan berumah tangga itu dianalogikan dengan rasa 'kepemilikan' antar satu dengan yang lain dan dianalogikan dengan kosa kata perkebunan dan bercocok tanam karena secara logika, ladang atau kebun diumpamakan sebagai lahan dan sumber kehidupan, jika ingin mendapatkan hasil panen yang bagus maka segala sesuatu sebelum hingga sesudah panen pun kebun tersebut selalu dijaga dan dirawat, jika ada yang masuk dalam kebun tersebut maka dirasa mengganggu dan adanya ancaman terhadap usaha bercocok tanam atau apa yang dipupuk sebagai hasil kelak tersebut. Kebun identik dengan sumber penghidupan dan rasa kepemilikan. Kebun berarti diartikan adalah batasan ranah rumah tangga pribadi yang menjadi sumber kebahagiaan dan sumber keberlangsungan kehidupan berketurunan. Hal ini dapat diketahui dari isi Kabanti pada bait berikut:

Kaapaakao 'adatina kadadi

Beapesua inuncana koinawuna

Asuru-suru gauna beaakandea

Sabaraaka antonay inawu itu

Artinya:

Masalahnya adat kebiasaan hewan

Ingin selalu masuk di kebun orang

Dia memaksakan ingin memakan tanaman

Segala tanaman isi kebun itu

Hal tersebut juga sesuai dengan apa yang terkandung dalam ajaran islam yang menganggap perbuatan zina adalah perbuatan yang berdosa besar terlebih lagi jika sampai melakukannya dengan istri orang lain sehingga kehancuranpun menjadi hukuman yang nyata bagi nya. Bahkan dalam delapan bait di mulai dari bait ke 63 sampai bait ke 70 dijelaskan tentang tindakan yang harus ditempuh untuk memberikan hukuman dan pelajaran bagi si 'perusak kebun 'tersebut. Bahkan hukuman zina yang teramat pedih dalam islam pun juga di aminkan dalam Kabanti ini sebagai balasan bagi pezina yang merusak rumah tangga sesamanya. Salah satunya dapat dilihat pada bait ke-64 berikut:

Aosemeya mokoinawunayitu

Teemaduka kawana atudaiya

Akaradeya kawana akantobua

Teemoduka inciyaatembaiya

Artinya:

Hewan itu diburu dipunya kebun

Sampai pula hewan itu dilempar

Ditombaki ataupun ditusuk-tusuk

Bahkan sampai pulaia di tembak

Adapun jika kesemua syarat, tuntunan dan larangan tersebut diikuti tanpa ada pelanggaran maka dalam Kabanti Kaluku Panda ini di jelaskan pada bait ke-56 yang isinya menjelaskan bahwa adanya rahmat dan keberkahan dalam rumah tangga tersebut dan ada rahmat pula dalam bibit atau generasi yang dikandung tersebut. Artinya konsep rumah tangga yang sakinah, mawaddah dan rohmah dapat tercapai dan menghasilkan keturunan yang baik dan berwibawa.sehingga keturunan tersebut menjadi kebanggaan keluarga, masyarakat bahkan negara. Bait tersebut berbunyi:

Kalimbunguna anamisimo isyqi

Momatu'ana kawondo ni'mati

Osiytumo tandaina rahmati

Kalabiana wine inciyasiytu

Artinya:

Kelapa mudanya memberi rasa asyik

Kelapa tuanya menyebar harum nikmat

Demikian itu sebagai pertanda rahmat

Keunggulan bibit yang demikian itu 


\section{SANG PENCERAH}

Volume 3, Nomor 2, Agustus 2017, Hlm. 39-49

Kosilah: Mengenal Identitas Masyarakat Buton melalui Konsep ...

Penjelasan yang penulis tuangkan dalam penjelasan di atas adalah disesuaikan dengan pembahasan yang diperlukan sehingga urutan bait tidak menjadi hal yang mengikat, karena esensi dalam mengambil nilai dan pelajaran dalam Kabanti ini pada dasarnya adalah sama saja yang penting tidak merusak, tidak memutar balikan dan tidak mengurangi keluhuran esensi nilai yang termuat di dalamnya.

\section{Simpulan}

Simpulan penelitian ini adalah bahwa identitas masyarakat Buton yang menjunjung tinggi nilai kebersamaan menuju kebahagiaan dalam menjalin hubungan baik dalam kehidupan berkeluarga ataupun bermasyarakat menunjukkan selaras dengan identitas bangsa Indonesia yang tertuang dalam pancasila. Keyakinan terhadap Tuhan yang Maha Esa, konsep bermasyarakat dan berumah tangga yang harmonis berdasar ajaran agama islam menjadi isi yang dominan dalam Kabanthi Kaluku Panda ini.

Pandangan hidup suatu bangsa adalah suatu kristalisasi dari nilai-nilai yang dimiliki oleh bangsa itu sendiri, yang diyakini kebenarannya dan menimbulkan tekad pada bangsa itu untuk mewujudkannya. Nilai-nilai yang terkandung dalam masyarakat Buton yan tertuang dalam Kabanthi Kaluku Panda ini hingga sekarang masih diyakini dan ditaati. Sehingga nilai-nilai yang positif dan mengandung keluhuran ini menjadi penanda identitas masyarakat buton bahwa dalam kehidupan berkeluarga berpegang pada konsep Islam demi terciptanya kehidupan yang penuh kasih sayang dan berketurunan yang baik,sehingga keberlangsungan kehidupan bermasyarakat dapat ditandai bahwa dengan usaha menciptakan keturunan dan generasi yang baik maka kehidupan sosial bermasyarakat menjadi lebih baik pula sistem sosial yang akan diciptakan. Identitas bangsa Indonesia yang toleran, gotong royong, membina persatuan dan keadilan sosial menjadi identitas yang linear dengan identitas masyarakat Buton yang menjaga secara berkesinambungan dalam berkehidupan sosial masyarakat. Kabanthi Kaluku Panda ini berisi mengenai konsep berkeluarga masyarakat Buton yang mempunyai konsep membangun keluarga yang sakinah, mawaddah wa rohmah sesuai dengan konsep islami. Dengan demikian identitas masyarakat Buton dapat diketahui dan dikenal sebagai masyarakat yang pada dasarnya selaras dengan nilai-nilai islam dan tidak berolak belakang dengan apa yang terkandung dalam identitas bangsa Indonesia ini.

\section{Daftar Pustaka}

Darmawan, M. Yusran (ed). 2009. Naskah Buton, Naskah Dunia. Baubau: Respect.

Friedman, M Marilyn. 2012. Buku Ajar Keperawatan Keluarga. Yogyakarta: Gosyen Publishing.

Kobu, La Ode (terj-Arif Rahman). 2003. Kaluku Panda, Tembang Berbahasa Wolio Buton.

Maula, Muhammad Jadul dkk. 2011. Kesepakatan Tanah Wolio, Ideologi Kebhinekaan dan Eksistensi Budaya Bahari di Buton. Depok: Titian Budaya bekerjasama dengan Pemda Kota Baubau dan FISIP UI.

Palalloi, Hamzah (ed). 2011. Kota Baubau Sejarah dan Perjalanannya. Baubau: Badan Komunikasi Informasi dan pengolahan Data. 


\section{SANG PENCERAH}

Volume 3, Nomor 2, Agustus 2017, Hlm. 39-49

Kosilah: Mengenal Identitas Masyarakat Buton melalui Konsep ...

Sudarsono. 1992. Hukum Perkawinan Nasional. Jakarta: Rineka Cipta.

Wahyono, Tries Edy. 2009. Pendidikan Multikultural. Malang: Surya pena Gemilang.

Widagdho, Djoko dkk. 2008. Ilmu Budaya Dasar. Jakarta: Bumi Aksara.

Zaadi, La Ode. 2005. Mengenal Kebudayaan Buton. Baubau. CV Sambalangi.

Zaitunah, Subhan. 2004. Membina Keluarga Sakinah. Yogyakarta: Pustaka Pesantren 